\title{
Aktivitas Antibakteri Ekstrak Daun Widuri Terhadap Escherichia Coli Dan Staphylococcus Aureus
}

\author{
Antibacterial Activities Of Widuri Leaves Extract On Escherichia Coli \\ And Staphylococcus Aureus
}

\author{
Siti Zamilatul Azkiyah \\ Program Studi Farmasi, Fakultas Ilmu Kesehatan, Universitas Ibrahimy \\ Email: st.zamilatulazkiyah@gmail.com
}

\begin{abstract}
ABSTRAK
Pentingnya penanggulangan infeksi bakteri menggunakan antibiotik adalah hal yang lazim dalam terapi farmakologi. Dampak dari pemberian antibiotik masih belum maksimal dalam penanggulangannya terhadap infeksi bakteri. Pemilihan alternatif bahan alam dengan kandungan kimia yang memiliki potensi sebagai antibiotik dapat menjadi pilihan lain dalam mengurangi penggunaan antibiotik sintetik, misalnya tanaman widuri (Calotrophis gigantean). Tujuan dari penelitian ini yaitu untuk mengetahui aktivitas antibakteri ekstrak daun widuri terhadap Escherichia coli dan Staphylococcus aureus. Desain penelitian meliputi identifikasi sampel, ekstraksi, hingga uji aktivitas dengan mengamati zona hambat dari kedua bakteri uji. Hasil penelitian menunjukkan bahwa ekstrak etanol $70 \%$ daun Widuri memiliki aktivitas antibakteri dan dapat menghambat pertumbuhan bakteri Escherichia coli dan Staphylococcus aureus. Senyawa aktif yang diduga bersifat antibakteri pada ekstrak etanol daun Widuri adalah senyawa golongan flavonoid, alkaloid dan terpenoid.
\end{abstract}

Kata Kunci: Daun Widuri, Escherichia coli, Staphylococcus aureus, Antibakteri

\begin{abstract}
Antibiotics have a very important role in fighting bacterial infections in the body. However, the results given so far have not been optimal in overcoming the problem of bacterial infection. An alternative solution is to develop and study plants that have medicinal potential, for example thistle leaves (Calotrophis gigantean). The purpose of this study was to determine the antibacterial activity of thistle leaf extract against Escherichia coli and Staphylococcus aureus. This research is a laboratory-scale experimental research that is to test the activity of thistle leaf extract against Escherichia coli and Staphylococcus aureus including sample identification, extraction, activity testing by observing the inhibition zone of the two tested bacteria. Based on the results of the study stated that the ethanol extract of $70 \%$ Widuri leaves (Calotrophis gigantea) had antibacterial activity and could inhibit the growth of Escherichia coli and Staphylococcus aureus bacteria. The active compounds that are thought to have antibacterial properties in the ethanol extract of Widuri leaves (Calotrophis gigantea) are flavonoids, alkaloids and terpenoids.
\end{abstract}

Keywords: Widuri leaves, Escherichia coli, Staphylococcus aureus, Antibacterial

\section{PENDAHULUAN}

Penyakit infeksi merupakan penyakit dengan tingkat kejadian terbesar hingga dapat menyebabkan tingkat kematian yang tinggi terutama di negara berkembang. Penanggulangan kasus infeksi melalui pemberian antibiotik belum mendapatkan hasil 
yang maksimal karena setiap bakteri memiliki tingkat resistensi yang berbeda terhadap cara kerja suatu antibiotik. Resistensi terhadap suatu infeksi oleh patogen tertentu dapat menimbulkan reaksi yang berbeda dalam setiap makhluk hidup. Oleh karena itu tingkat kematian yang disebabkan oleh infeksi bakteri dapat mengalami peningkatan (Pelczar dan Chan, 1988).

Indonesia merupakan salah satu negara dengan keanekaragaman tanaman yang tinggi dan berpotensi sebagai obat. Para peneliti juga telah banyak melakukan kajian dan penelitian terkait potensi tanaman sebagai alternatif pengobatan. Belum tersebar merata tiap sarana dan prasarana kesehatan dalam setiap daerah dapat menyebabkan rendahnya cakupan akses dalam mendapatkan pelayanan kesehatan dan pengobatan. Sehingga mayoritas masyarakat masih bergantung pada tanaman obat secara tradisional dalam mencegah dan mengobati penyakit. Hal ini dikarenakan lebih mudah didapatkan dan murah secara ekonomis (Dirjen POM, 1995).

Tanaman widuri (Calotrophis gigantean) merupakan salah satu tanman yang berpotensi sebagai bahan obat, sehingga beberapa peneliti melakukan kajian terhadap kandungan dan khasiat dalam tanaman tersebut (Alam, 2000). Beberapa penelitian menguraikan bahwa tanaman widuri memiliki efek farmakologi sebagai antimikroba, analgesik dan sitotoksik terhadap Artemia salina (Habib \& Karim, 2009). Daun widuri dapat bersifat sebagai antidiare (Chitme et al, 2004) dan antibakteri (Kumar et al, 2010), serta bagian aakar terbukti sebagai antipiretik (Chitme et al, 2005), antimikroba dan insektisida (Alam et al, 2009). Getah tanaman widuri dapat memberikan efek purgatif, prokoagulan, wound healing. Batang widuri mempunyai efek hepatoprotektor (Lodhi et al, 2009).

Antibakteri dapat mempengaruhi pertumbuhan atau menghambat perkembangbiakkan suatu mikroorganisme, sehingga dalam mengetahui efektifitasnya dapat dilakukan uji aktivitas antibakteri. Bakteri yang umum menyebabkan penyakit infeksi adalah Escherichia coli dan Staphylococcus aureus. Bakteri tersebut merupakan bakteri patogen yang sering menyebabkan penyakit infeksi. Tujuan penelitian ini yaitu untuk mengetahui aktivitas antibakteri 
ekstrak daun widuri terhadap Escherichia coli dan Staphylococcus aureus.

\section{METODE PENELITIAN}

Penelitian ini merupakan penelitian ekperimen skala laboratorium dengan melakukan uji aktivitas ekstrak daun widuri terhadap penghambatan bakteri Escherichia coli dan Staphylococcus aureus yang meliputi identifikasi sampel dan ekstraksi, hingga uji aktivitas antibakteri dengan mengamati zona hambat yang terbentuk setelah pemberian ekstrak daun widuri. Penelitian ini dilakukan di Laboratorium Mikrobiologi Program Studi Farmasi Fakultas Ilmu Kesehatan, Universitas Ibrahimy. Penelitian dilakukan pada bulan September 2018 sampai dengan Februari 2019.

Alat yang digunakan terdiri dari autoklaf , bejana maserasi, batang pengaduk, botol coklat, cawan petri, cawan porselin, inkubator, kompor gas, Laminar Air Flow (LAF), lampu spirtus, lemari pendingin, oven, jarum ose, penangas air, pinset, rak tabung, rotary evaporator, sendok besi, sendok tanduk, tabung reaksi,, alat vortex, neraca analitik, kaca arloji, Erlenmeyer $500 \mathrm{~mL}$, aluminium foil, gelas ukur 100
$\mathrm{mL}$, beaker glass $100 \mathrm{~mL}$, kertas sarig, penyaring, corong, botol vial, desikator. Adapun bahan yang digunakan meliputi bakteri Escherichia coli, etanol 70\%, Staphylococcus aureus, aquades, Nutrien Broth Agar, silikal gel 60 GF 254, media NA.

\section{Pembuatan Ekstrak Daun Widuri}

Tahap awal penelitian ialah dengan mengumpulkan sampel daun widuri di area Sukorejo, Banyuputih, Jawa Timur. Daun dicuci dengan air bersih dan mengalir untuk menghilangkan kotoran yang menempel pada daun dan selanjutnya dipotong kecil-kecil lalu dikeringkan dengan dianginkan hingga daun kering supaya kadar airnya berkurang. Sampel daun widuri yang sudah kering selanjutnya dihaluskan menggunakan blender dan diayak selanjutnya disimpan dalam wadah.

Tahapan selanjutnya ditimbang serbuk daun widuri sebanyak 400 gram sampel untuk diekstraksi melalui metode maserasi dalam elarut etanol 70\%. Ekstraksi pertama dengan merendam 400 gram sampel ke dalam pelarut etanol $70 \%$ 2L selama 24 jam dalam wadah tertutup, kemudian dilakukan pengadukan selama 3 jam. Setelah itu disaring untuk memisahkan 
antara filtrat dan residu, kemudian ampasnya dikeringkan dari pelarutnya dan dilakukan pengulangan sebanyak 3 kali dengan perlakuan yang sama. Ampas yang telah kering direndam kembali untuk mendapatkan hasil yang maksimal. Hasil ekstrak yang diperoleh selanjutnya diuapkan menggunakan rotary evapotaor sehingga memperoleh ekstrak pekat yaitu berupa crude ekstrak. Tujuan penguapan tersebut untuk memisahkan antara pelarut dengan senyawa yang terkandung dalam daun widuri.

\section{Sterilisasi Alat}

Alat-alat yang diperlukan dicuci terlebih dahulu dan dikeringkan dengan posisi terbalik di udara terbuka, serta dibungkus dengan kertas tahan panas. Tabung reaksi dan gelas Erlenmeyer terlebih dahulu disumbat dengan kapas bersih. Semua alat gelas disterilisasi menggunakan oven pada suhu $140^{\circ} \mathrm{C}$ selama 2 jam. Alat yang tidak tahan terhadap pemanasan dengan suhu tinggi dapat disterilkan menggunakan autoklaf pada suhu $121^{\circ} \mathrm{C}$ selama 15 menit dengan tekanan 2 atm. Jarum inokulasi atau ose disterilkan dengan cara dipijarkan secara langsung dengan api bunsen.

\section{Persiapan Bakteri Uji}

Bakteri uji digunakan dalam penelitian ini meliputi Escherichia coli, Staphylococcus aureus. Bakteri-bakteri ini berasal dari Laboratorium Mikrobiologi Farmasi Universitas Ibrahimy yang diremajakan atau ditumbuhkan dalam media NA dan diinkubasi selama 24 jam pada suhu $37^{\circ} \mathrm{C}$.

\section{Uji Aktivitas Antibakteri}

Pada tahap skrining aktivitas, ekstrak etanol dilarutkan dalam dimetilsulfoksida (DMSO), kemudian dicampurkan dengan media NA yang telah dicairkan. Selanjutnya campuran tersebut dituangkan ke dalam cawan petri dan digoyang-goyangkan agar merata dan dibiarkan memadat. Biakan mikroba uji encer lalu diratakan dengan menggunakan metode surface plate, kemudian cawan petri diinkubasi pada suhu $37^{\circ} \mathrm{C}$ selama 24 jam.

Lempengan sebelumnya dilakukan elusi terlebih dahulu, kemudian lempengan diletakkan diatas permukaan media agar yang telah diinokulasi bakteri uji. Langkah selanjutnya diinkubasi pada suhu dan waktu tertentu hingga biakan bakteri tumbuh dan tampak adanya zona 
hambat terhadap bakteri uji dalam cawan petri.

Analisis data pada penelitian ini dimaksudkan untuk mengetahui ada tidaknya pengaruh terhadap objek yang digunakan atau melihat ada tidaknya hubungan sebab akibat. Dalam mengetahui hasilnya dilakukan dengan membandingkan satu atau lebih kelompok uji yang diberi perlakuan dengan satu atau lebih kelompok pembanding yang tidak diberi perlakuan. Hasil uji disajikan dalam bentuk tabel hasil zona hambat aktivitas antimikroba bakteri uji.

\section{HASIL DAN PEMBAHASAN}

Berdasarkan hasil ekstraksi daun widuri dengan metode maserasi menggunakan etanol $70 \%$ diperoleh ekstrak sebanyak 46 gram. Hasil pengujian antibakteri ekstrak etanol $70 \%$ daun widuri dengan cara mengukur dan mengamati adanya zona hambat pada kertas cakram. Nampak bahwa ekstrak etanol $70 \%$ daun widuri dapat menghambat pertumbuhan bakteri yang ada dalam media biakan. Berikut tabel hasil pengukuran zona hambat uji aktivitas antibakteri dari ekstrak etanol $70 \%$ daun widuri.
Tabel 1. Hasil Pengujian Aktivitas antibakteri Ekstrak Etanol 70\% Daun Widuri

\begin{tabular}{ccc}
\hline $\begin{array}{c}\text { Ekstrak } \\
\text { Daun widuri } \\
\text { (cawan petri) }\end{array}$ & $\begin{array}{c}\text { Zona Hambat (cm) } \\
\text { Eschichia } \\
\text { coli }\end{array}$ & $\begin{array}{c}\text { Staphylococcus } \\
\text { aureus }\end{array}$ \\
\hline 1 & 0.5 & 0.1 \\
2 & 0.6 & 0.2 \\
3 & 0.5 & 0.3 \\
4 & 0.7 & 0.5 \\
5 & 0.7 & 0.5 \\
\hline
\end{tabular}

\section{Daun widuri dikumpulkan} sekitar pukul 09.00 pagi karena saat itulah terjadi fotosintesis maksimum. Sebelum dilakukan proses ekstraksi, daun widuri yang telah dipetik terlebih dahulu disortasi basah. Sortasi basah bertujuan untuk menghilangkan atau memisahkan kotoran dan bahan asing lainnya yang tidak dibutuhkan. Selanjutnya daun dicuci bersih menggunakan air bersih dan mengalir sehingga kotoran yang melekat pada daun hilang. Pencucian juga harus memperhatikan lama waktu karena ada beberapa bahan yang memiliki kandungan senyawa mudah larut dalam air. Kemudian dilakukan proses pengeringan dengan cara dikering anginkan di dalam ruangan agar tidak terpapar sinar matahari secara langsung. Tujuan pengeringan sampel agar dapat mengurangi kadar air dalam sampel, menghentikan proses enzimatik dan rusaknya bahan karena adanya 
pertembuhan mikroba yang dipicu oleh adanya air.

Sampel yang digunakan berupa simplisia yang berupa serbuk dan dilakukan ekstraksi dengan menggunakan metode maserasi (ekstraksi dingin atau tanpa pemanasan), pemanasan pada bahan dapat merusak senyawa kimia yang terdapat dalam sampel. Maserasi dilakukan dengan menggunakan pelarut etanol $70 \%$ dan dalam ruangan tertutup untuk menghindari pengaruh cahaya (sinar matahari) terhadap stabilitas senyawa-senyawa yang akan diambil.

Setelah diperoleh ekstrak etanol kental, kemudian dilanjutkan uji aktivitas antibakteri terhadap bakteri E. coli dan S. aureus. Pengujian dilakukan dengan menggunakan metode difusi agar dengan cara menggoreskan biakan bakeri pada media agar atau media NA yang telah di campur dengan ekstrak etanol daun widuri.

Adapun pemilihan jenis-jenis bakteri uji tersebut karena sifat-sifat yang patogenik. Baktei E. coli merupakan bakteri anaerob dan termasuk dalam golongan bakteri Gram negative sebagai penyebab utama diare kronik. Sedangkan bakteri S. aureus merupakan bakteri berbentuk kokus dan termasuk dalam bakteri gram positif. Bakteri tersebut sebagai patogen penyebab infeksi kulit hingga menyebabkan luka kronik.

Hasil penelitian menunjukkan bahwa ekstrak etanol $70 \%$ daun widuri memberikan aktivitas penghambatan terhadap bakteri uji Escherichia coli dan Staphylococcus aureus. Hal ini dapat dilihat pada tabel 4.1 yang menunjukkan adanya zona hambat pertumbuhan bakteri setelah pemberian sampel. Pengamatan secara umum terlihat bahwa dalam lima kali ulangan pada kedua jenis bakteri uji menunjukkan bahwa rata-rata zona hambat terhadap bakteri E. coli lebih besar dari pada bakteri S. aureus.

Kertas cakram ditempatkan di atas permukaan media agar yang telah memadat dan diinokulasilasi dengan bakteri sensitif terhadap senyawa antibakteri yang dianalisis. Setelah 1530 menit, lempeng kromatografi diangkat dari permukaan media kemudian diinkubasi selama 1 x 24 jam pada suhu $37^{\circ} \mathrm{C}$. Senyawa antibakteri yang telah berdifusi dari lempeng kromatogram ke dalam media agar akan menghambat pertumbuhan bakteri sehingga dapat membentuk zona bening pada medium agar. 
Prinsip kerja antimikroba yaitu melalui aktivitas toksisitas yang selektif, dimana senyawa uji lebih toksik terhadap mikroorganisme dibandingkan pada sel hospes. Hal ini dapat disebabkan oleh efek selektif senyawa uji atau obat terhadap mikroorganisme (Djide, 2008). Salah satu mekanisme kerja antibiotik ialah melalui aktivitas penghambatan sintesis dinding sel dengan cara merusak dinding sel mikroba, menghentikan atau inaktivasi enzim sehingga menyebabkan hilangnya viabilitas hingga selnya lisis. Rusaknya dinding sel akibat antibiotik dengan menganggu aktivitas sintesis peptidoglikan (Suwandi,1992). Fungsi dinding sel bakteri yaitu memberikan bentuk, melindungi bagian dalam sel terhadap perubahan luar seperti tekanan osmotik dan kondisi lingkungan lainnya yang merugikan. Proses biokimia sel berlangsung di dalam sel yaitu bagian sitoplasma sel. Oleh karena itu, dengan adanya pengahambatan dalam proses akhir sintesis dinding sel maka menyebabkan membran kurang stabil secara osmotik hingga terjadi lisis sel (Suwandi, 1992).

\section{SIMPULAN DAN SARAN}

Ekstrak etanol 70\% daun Widuri (Calotrophis gigantea) memiliki aktivitas antibakteri terhadap pertumbuhan bakteri Escherichia coli dan Staphylococcus aureus. Senyawa aktif yang memiliki aktivitas antibakteri pada ekstrak etanol daun Widuri (Calotrophis gigantea) adalah senyawa golongan flavonoid, alkaloid dan terpenoid.

$$
\text { Saran pada penelitian }
$$
selanjutnya untuk menambah data ilmiah dari tanaman daun Widuri (Calotrophis gigantea), sebaiknya dilakukan penelitian mengenai isolasi komponen senyawa kimia dan elusidasi struktur senyawa yang berpotensi sebagai antibakteri.

\section{DAFTAR PUSTAKA}

Alam MA, Habib MR, Nikkon F, Rahman M, Karim MR. 2000. Antimicrobial activity of akanda (Calotropis gigantea L.) on some phatogenic bacteria.

Bangladesh J. Sci. Ind. Res. 43(3):397404. Anslyn EV, Dougherty DA. 2006. Modern Physical Organic Chemistry. Sausalito (US) : University Science Books.

Dalimartha S. 2008. Atlas Tumbuhan Obat Indonesia Jilid 2. Jakarta: Trubus Agriwidya. 
Dirjen POM. 1979. Farmakope Indonesia Edisi III. Deprtemen Kesehatan RI : Jakarta

Dirjen POM. 1995. Farmakope Indonesia Edisi IV. Deprtemen Kesehatan RI : Jakarta

Djide, M. N, Sartini. 2008. DasarDasar Mikrobioogi Farmasi. Lembaga Penerbitan Universitas Hasanuddin : Makassar

Ganiswara, Sulistia G. 1995. Farmakologi dan Terapi. Disi 4. Bagian Farmakologi Fakultas kedokteran. Universitas Indonesia : Jakarta.

Garrity. G. M., Bell. J. A. and Lilburn, T.G. 2004. Taconomic Outlineof The Prokaryotex bergey"s Manual of Systematic Bacteriolog. 2th Edition. United States of America, Springer, New York Berlin Hendelberg.

Gritter, R. J, Schwerting, A. E.1991. Pengantar Kromatografi. Edisi Kedua. Terjemahan Kosasih Panwawita. Penerbit ITB : Bandung.

Hermawan A, Hana W, Wiwiek T. 2007. Pengaruh ekstrak daun sirih (Piper betle L.) terhadap pertumbuhan Staphylococcus aureus dan Escherichia coli dengan metode difusi [skripsi]. Surabaya (ID) : Universitas Erlangga. Idris M. 2013. Efektifitas ekstrak Aloe vera terhadap pertumbuhan bakteri Streptococcus sanguis. [skripsi]. Makassar (ID): FKG Universitas Hassanudin.
Jaiswal J, Srivastava S, Gautam H, Sharma S. 2013. Phytochemical screening of Calotropis gigantea (Madar) seeds extracts. IJPRS. 2(2):235-238. Kirby WM, Roberts CE, Bauer AW. 1959. Single-disc antibiotic sensitivity testing of Staphylococci. Arch, Intern. Med. 1004:208-216. Kresnawaty I, Zainuddin A. 2009. Aktivitas antioksidan dan bakteri dari derivate metil ekstrak etanol daun gambir (Uncaria Gambir). Jurnal Littri. 15(4):145-151.

Krishanu S, Divyansh M. 2013. Pleminary physicophytochemical and phytocognostical evaluation of the leaves of Calotropis gigantea (L.) R. BR. IJPCS. 2(4):1832-1838.

Kumar G, Karthik L, Rao KVB. 2010. Antibacterial activity of aqueous extraxt of Calotropis gigantea leaves-an in vitro study. International Journal of Pharmaceutical Sciences Review and Research. 4(2): 141144.

Kumar SS, Sivamani P, Baskaran C, Mohamed MJ. 2012. Evaluation of antimicrobial activity and phytochemical analysis of organic solvent extracts of Calotropis gigantea. IOSR Journal of Pharmacy. 2(3):389394.

Kusmiyati, Agustini NWS. 2007. Uji aktivitas senyawa antibakteri dari mikroalga Porphyridium cruentum. Biodiversitas. 8: 4853. 
Kusumaningtyas E, Widiati RR, Gholib D. 2008. Uji daya hambat ekstrak dan krim ekstrak daun sirih (Piper betle) terhadap Candida albicans dan Trichophyton mentagrophytes. Seminar Nasional Teknologi Peternakan dan Veteriner. 805812.
Marliyana SD, Handayani N, Ngasah S, Setyowati EN. 2013. Aktivitas antibakteri minyak atsiri daun sirih merah (Piper crocatum Ruiz \& Pav.). Alchemy Jurnal Penelitian Kimia. 9(2):33-40.

Suwandi, U. 1992. Mekanisme Kerja Antibiotik. Pusat Penelitian dan Pengembangan. PT Kalbe Farma : Jakarta 